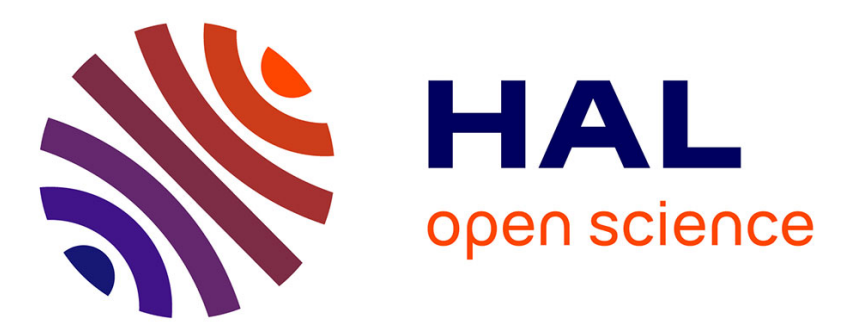

\title{
The Shatila soundscape: Sound cultures, practices, and perceptions in a refugee camp in Lebanon
}

\author{
Nicolas Puig
}

\section{To cite this version:}

Nicolas Puig. The Shatila soundscape: Sound cultures, practices, and perceptions in a refugee camp in Lebanon. Violence: An international journal, 2020, Sounds of survival, weaponization of sounds, 1 (2), pp.285-302. 10.1177/2633002420961399 . hal-03177056

\section{HAL Id: hal-03177056 https://hal.science/hal-03177056}

Submitted on 22 Mar 2021

HAL is a multi-disciplinary open access archive for the deposit and dissemination of scientific research documents, whether they are published or not. The documents may come from teaching and research institutions in France or abroad, or from public or private research centers.
L'archive ouverte pluridisciplinaire HAL, est destinée au dépôt et à la diffusion de documents scientifiques de niveau recherche, publiés ou non, émanant des établissements d'enseignement et de recherche français ou étrangers, des laboratoires publics ou privés. 


\title{
The Shatila soundscape: Sound cultures, practices, and perceptions in a refugee camp in Lebanon
}

(C) The Author(s) 2020

Article reuse guidelines: sagepub.com/journals-permissions DOI: 10.1 I77/263300242096I399 journals.sagepub.com/home/vio

\section{Nicolas Puig}

Université de Paris, URMIS, IRD, CNRS, France

\begin{abstract}
This article discusses certain key questions about the history, memory, and dynamics of belonging in Palestinian refugee camps in Lebanon based on the sound culture of their inhabitants. What can the musical content, in particular, and the sound environment, in general, generated by the neighborhood, the birds, and the scooters circulating in the narrow alleys, tell us about life in one of those camps and about the daily lives of a national group placed on the margins of citizenship for over 70 years? Taking the example of the Shatila refugee camp in Beirut, the following three dimensions of this sound culture are examined: the discourses on the community and its spaces in musical production (singing about the camp); sound practices inside the camp (sonorizing the camp); and finally, the description of the camp and its surroundings by its residents through sound journeys (listening to the camp). The analysis is first based on the content of songs in order to describe what music expresses about life in the refugee camps. It then moves on to examine the ordinary sound practices which contribute to the unique character of Shatila and its surrounding areas, such as the commercial district of Sabra. Third, perceptions of the spaces by the residents are described using the method of sound journeys (using the "Mics in the ears" procedure). Finally, it turns out that sound practices give the refugee camp-which over time has turned into a poor cosmopolitan district-a specific identity, and they contribute to establishing a familiarity with the spaces while nonetheless creating boundaries between the groups. These practices fulfill the needs of all the inhabitants to act in and upon the space where they live, this urban margin where they have been "confined" for a long time.
\end{abstract}

\section{Keywords}

Palestine, refugees, Shatila, sound cultures and practices, sound perceptions

\section{Corresponding author:}

Nicolas Puig, Université de Paris, URMIS, IRD, CNRS, F-750I 3 Paris, France.

Email: nicolas.puig@ird.fr 


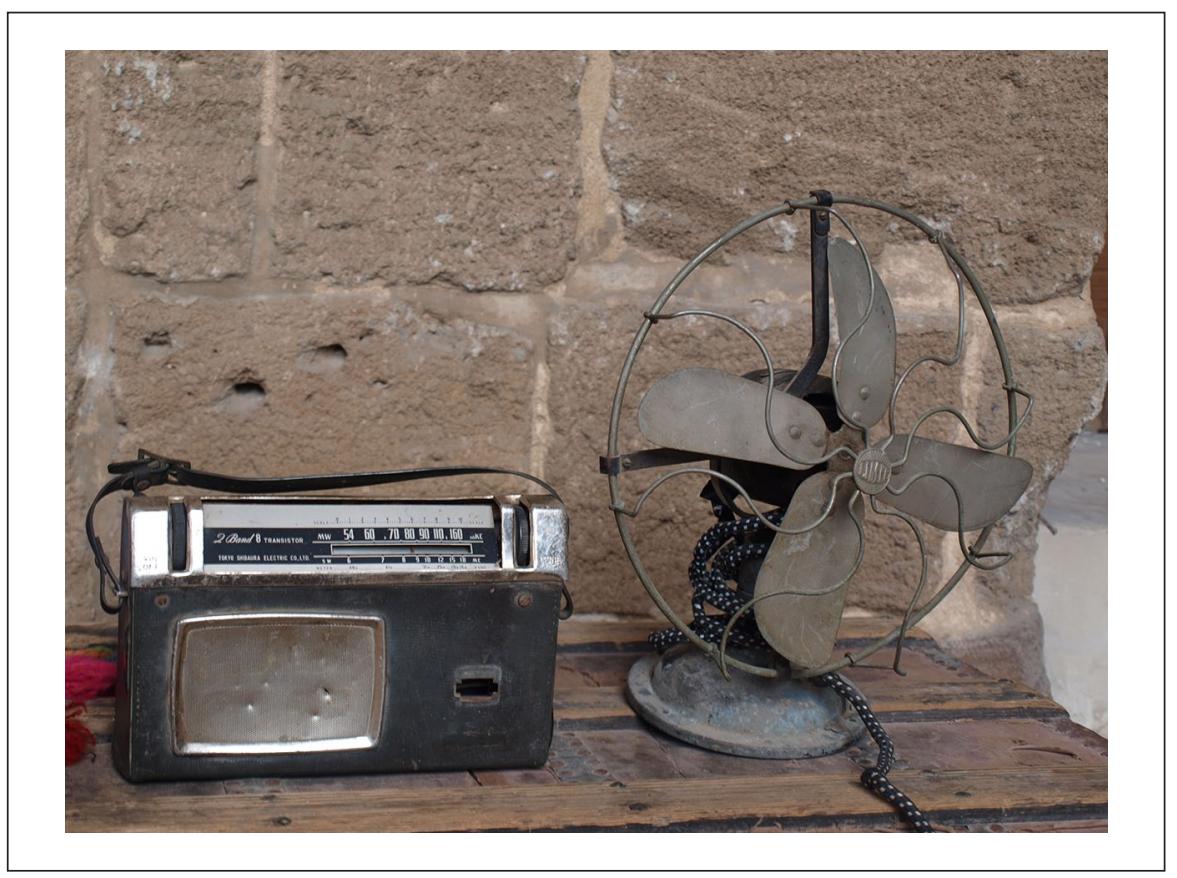

Picture I. Exhibition of Palestinian objects, Sidon, 2017, all photos by the author.

Sidon, Lebanon, October 2017: Khan El Franj, a 17th-century caravanserai situated at the entrance of the old town, hosts a Palestinian festival for 2 days. The speeches, concerts, and poetry recitals are accompanied by exhibitions of emblematic artifacts of Palestinian culture outside the big domed hall of the khan. The Association for Heritage Objects, presided by a Palestinian refugee in Lebanon, Abū Rashīd al-Mī’ārī, who gave his name to the association, then called $a l-M \bar{\imath}$ ' $\bar{r} r \bar{l}$ lil-turātiyyāt, presents some objects of the daily lives of Palestinians from before the 1948 exile. While music and songs can be heard from the hall and reverberate in the interior courtyard, a radio and fan displayed on a wooden chest, which is also a relic from the Palestinian Mandate, remain inanimate (Picture 1). Their inanimate silence contrasts strikingly with the sounds from the hall, and underlines their status as witnesses from the pre-exilic past of the Palestinian refugees in Lebanon. Al-Mī'ārī confides in me: "You know, someone who neglects their history has no nationality." If silent objects from the past remind the community of its history, what of those which populate its present and which contribute to shaping its sound environment?

In this study, I would like to examine these key questions of history, of memory, and of the dynamics of belonging, not directly face on-since much historical and anthropological research has already been done on this topic ${ }^{1}$ - but by inserting them in an acoustic continuum which, from music to the sounds of daily life, describes the elements of a "sound culture" in the Palestinian refugee camps of Lebanon. What can the musical content, in particular, and the sound environment, in general, generated 
by the neighborhood, the birds, and the scooters circulating in the narrow alleys, tell us about life in one of these camps and about the daily lives of a national group placed on the margins of citizenship for over 70 years? The Palestinian refugees are often confined in these spaces of poverty, which today have the appearance of deteriorated districts of the city, while their designation as "camps" refers more to the status of the space and of those who live there rather than to a precise urban structure. The transformations of the sound environment and the creation of a shared "sound culture" could enable us to grasp clearly how the group maintains itself in the long term. This culture, which Jonathan Sterne (2003) refers to as "an overarching, shared sensibility," is historicized, just like visual culture is, and should be recomposed through analysis based on "a bewildering array of stories about speech, music, technology, and other sound-related practices" (p. 4). It manifests itself in lifestyles, aesthetic tastes, imagination, and listening habits. The approach adopted in this article is based on an interest which has become well established since the pioneering work of R. Murray Schafer (1994 [1977]) on the soundscape, which aims to "broach man and the world from the point of view of the sound dimension" (Augoyard, 2003: 26) ${ }^{2}$ in a scientific context where, usually, sociological and anthropological research give priority to visual phenomena and sight. The study of "audible modes" 3 thus offers "the concrete possibility to envisage social phenomena in a different way" (Augoyard, 2003) for the research which is presented here, for social relations, and for the creation of a sensory environment in the Palestinian camps.

From political and nationalist music, structured by the pressing need of memory and the dread of the community's dispersion, to the festive music of wedding and engagement rituals, the music of the camps creates an artistic range which is strongly determined by the situation of refuge (Puig, 2009). I propose here to describe the following three new dimensions of the sound culture of the Palestinians in Lebanon: the discourses on the community and its spaces (the camps) in musical production, sound practices inside the camp, and finally, the description of the camp and its surroundings by the inhabitants based on a sound journey, using the "Mics in the ears" procedure (Battesti and Puig, 2016, 2020). The analysis will first be based on the content of songs to describe what music expresses about life in the refugee camps. Second, it will examine the Shatila camp and the gatherings ${ }^{4}$ of Sabra: an area of $1 \mathrm{~km}^{2}$, Shatila had a population of 14,010 in 2017 (including its neighboring districts, it had between 22,000 and 30,000 inhabitants in 2014 according to the sources of Hala Abou $\mathrm{Zaki}^{5}$ ). The analysis will describe in detail the ordinary sound practices which contribute to the specificity of this space and its surrounding districts, such as Sabra's commercial district. Third, I will describe the perceptions of these spaces by the inhabitants using the method of sound journeys. Finally, I will discuss the existence of an acoustic community based on a certain number of "sound markers," also termed soundmarks (Schafer, 1994 [1977]: 10), which are specific to the camps and which create a boundary between the long-settled Palestinian residents and people who have arrived more recently, mostly from Syria.

Three quarters of the Palestinian refugees in Lebanon live in the camps and gatherings, thereby finding themselves living on the fringe and confronted by their difference. Twelve in number, these camps are managed by an agency of the United Nations which has sole responsibility for the Palestinian refugees in the Near East, the United 
Nations Relief and Works Agency (UNRWA). ${ }^{6}$ These spaces embody the discriminatory status to which the refugees have been reduced since their arrival in Lebanon in 1948, a status confounded by wariness toward them which sometimes borders on "a racism of nationality" on the part of some of the Lebanese population; the traumatic legacy of the civil war (1975-1990) has not improved relations, quite to the contrary. After 70 years in Lebanon, the Palestinian refugees are still considered foreigners and their governance "has been transferred to the hands of the police and military on the one hand, and to an apolitical relief organization such as the UNRWA, on the other hand" (Hanafi, 2010: 38).

The oldest refugees in the contemporary world, the Palestinians, more than any other group, are subject to the humanitarian regime which manages all the urban and social services in the camps, from health to education. Nonetheless, they continue to produce a discourse about themselves, which is perhaps less audible to the international audience than that of great poets and writers of the past such as Mahmoud Darwish or Ghassan Kanafani, but which does not stop them from tirelessly expressing their experience as refugees in its existential, but also political and social aspects.

\section{Singing about the camp}

In Lebanon, Palestinian songs do not often mention the issue of the camps, mainly out of respect for their Lebanese hosts. Indeed, it would be considered bad form to mention these spaces and how they signify the situation of the Palestinian refugees. Consequently, the orchestras of political and nationalist songs financed by organizations and parties focus on evoking the lost country, its people and its diaspora, its leaders (which vary according to the party supporting the group), the struggle against Zionism and, in general, the situation in Palestine. However, the camps are referred to on certain occasions, like in a song of a local variety ${ }^{7}$ produced around 2010 ("The Girl of the Camps," bint al-mukhayamāt ${ }^{8}$ ). This song by Mustafa Zamzam tells the story of a man who, after having met a young girl from the camps, searches for her everywhere, which is a pretext to list all the 12 camps in Lebanon with a strong Palestinian accent. More recently, this singer has written a song about the migration of the young people of the camps who all, almost without exception, yearn to leave Lebanon. Called "The Camp and Migration," the song is presented as,

a message from the camp to its children who migrated or who are thinking of migrating because migration is an adventure which abolishes the right to return and makes them forget the cause for which thousands became martyrs. They know that the camp is the first and the last stage for Palestine. (Facebook post of Mustafa Zamzam, 2015)

Before that, in 2007, a sudden confrontation between infiltrated Islamist fighters and the Lebanese army ended, after 3 months of conflict, in the destruction of the Nahr alBared camp in north Lebanon. The fate of that camp, which has been undergoing reconstruction ever since, has provoked the production of music which describes the tragedy in both words and music (Puig, 2014: 184).

However, it was with the release of an album by the Palestinian rap band Katība Khamsā (whose usual Latin transcription is Katibeh Khamseh, "five phalanxes") that life 
in the Palestinian refugee camps became an explicit theme in Palestinian cultural expression. Called "Welcome to the Camps" (Beirut, Incognito record company, 2008), this album is about aspects of individual and community life, in addition to the problems inside the camps. In the song "Jama'iyāt" ("Associations"), the rappers criticize "the political practices of clientelism and patronage which have dominated the camps for a long time" (Hanafi, 2010: 33). Conveying a tradition of social criticism, which is well understood by a new generation of singers, the rap which developed in the 2000s, mainly in the camps of Burj al-Barājnā (phonetically Bourj el-Barajneh) in Beirut and Ayn al-Halwā (Ain al-Hilweh) in Sidon takes into consideration the difficulties of daily life. The rappers find a vehicle of expression in this style which enables them to tackle the issue of the living conditions "here and now" (see Puig, 2010). The emergence of a new musical aesthetic in parallel to the nationalist song which appeared in the 1960s (Puig, 2009) has thus enabled the birth of a discourse on the camps, a discourse which was previously kept under wraps by political organizations for reasons of diplomacy toward their Lebanese hosts, as mentioned earlier. The issue of the camps as a living environment and a part of identity has therefore emerged in rap songs. The existence of "a camp mentality" which is specific to each one of the 12 Palestinian camps is well-known to the refugee inhabitants. The Nahr al-Bared crisis in 2007 underlined this differentiation when thousands of inhabitants from this camp in north Lebanon were obliged to seek refuge in the neighboring Beddawi camp. The overriding impression was that there were now "two camps in one" (Puig, 2014).

Rap has, therefore, expressed in music what was being said in private. These discourses question the management of the camps by confronting the UNRWA and the people's committees, which are accused of corruption and inaction. During one conversation, an inhabitant of the camp (who explained that he was the same age as the cause, having been born in 1948), parodying the famous slogan of the revolutionary years, told me humorously that al-thawra hatā an-nașr, "revolution until victory," has been replaced by al-faw ḍa hatā an-nașr, "chaos until victory."

In addition, one comes across Palestinian rap lyrics in Lebanon that tackle explicitly the theme of the camps as spaces of banishment, as well as the rivalry between young people of the different camps, like Shatila and Bourj el-Barajneh, situated $2 \mathrm{~km}$ apart south of Beirut. In the following extracts, the rappers of Katibeh Khamseh, who are originally from Bourj el-Barajneh, describe the young people of the two camps and their relations:

\section{Extract 1}

You must tolerate me a bit

So that I can talk to you a bit about the slow death we are subjected to

Little by little

It starts by hanging around at the end of the road

$[$. . .]

By the area between our district and the other district

The electricity cuts out again and again, and it burns

Yet it's sold as if we didn't know where it comes from 
As if no one knew where it comes from

A power switchboard lit by an unknown hand

The mood of the young people of Bourj [el-Barajneh] and Shatila is like gas under pressure

Bayna hayı̄ wa hayak ("Between My District and Yours"), 2011, lyrics and vocals by Jazzar, produced by Osloob.

\section{Extract 2}

The difference between my district and your district

Is only in our minds

Like the shadow which follows you

Whatever you have in your pocket, keep it!

And be happy if you're left with half

Instead of finding yourself in the slammer!

Let Bourj [el-Barajneh] tell Shatila about a new catastrophe, a new grass,

A new house

Destroyed (chorus)

New problems

Which they hide from us (chorus)

And don't let people's gaze define me and define you, because we both have the same things on our minds

So why do you ask me: "What's wrong with you?"

Why? Where do you guys come from?

Abdel-Jabbar, musical novel 'alal-hifiā, 2012, lyrics and vocals by Abdel-Jabbar, produced by Osloob.

Apart from contributing to the music of the camps by circulating on computers and smartphones, these songs play a part in the ambivalent perception of that space, which is both a deteriorated living space and preserves the national community. ${ }^{9}$ Their content contributes to the sound culture of the Palestinians in Lebanon, at least that of the new generations, and plays a role in establishing a "cultural intimacy" which constitutes a national social grouping.

However, the camp is now a shared space with non-Palestinian residents, mainly Syrians, some of whom have been there for a long time, but also Asian migrants, especially Bangladeshis.

These newcomers can also produce descriptions of the spaces in which they live. The latter have not (so far) been set to music and belong instead to the literary or poetic realm. Hasan, from Syria, has been living in Lebanon for around 10 years. ${ }^{10}$ He has been working for many years in a clothes shop located in Sabra market, and is renting a small tworoom ground floor flat in Shatila. Hasan is also a writer, and, among his numerous works, some briefly describe the atmosphere of the streets of Sabra and Shatila, including the sound dimension. In a text called "In the Jam-Packed Street," he describes "the din and confusion of people in the market" [of Sabra], "the tangle of children and passers-by in the rain" and also "the spring mist and shouts of children," recurring themes of the sound atmosphere of Sabra and of the camp. 
A discourse about the camp has emerged in cultural expression. The descriptions of Hasan, the rap songs, and the entreaties to young people by Mustafa Zamzam, all contribute to the accumulation of expressions about this space. We have yet to discover, however, how the inhabitants create and perceive sensory, and more specifically, sound, characteristics. To grasp what remains unknown territory to us about the camps, I focused on the different sounds produced in the Shatila-Sabra zone and on how this sound production could eventually be classified according to nationality (in particular, Palestinian and Syrian).

\section{Sonorizing the camp}

How does a Palestinian refugee camp in Lebanon "sound"? Does it have specific sounds? How do the inhabitants evaluate these sounds and how do they differentiate according to the national groups' relationship to the sound environment in the camps?

These questions prompt one to think about the relationship between the sounds and living in this particular space. In Lebanon, after more than 70 years of existence, the Palestinian camps have been transformed into precarious districts, sometimes very cosmopolitan, especially when they are integrated in towns (which is the case of part of the camps in Beirut, Tripoli, Sidon, and Tyr). ${ }^{11}$ The silence of the objects of the past, presented at the beginning of this article, contrasts with the sounds of today, the sounds of daily life which shape familiarity, kindle conflict, and provoke questions and

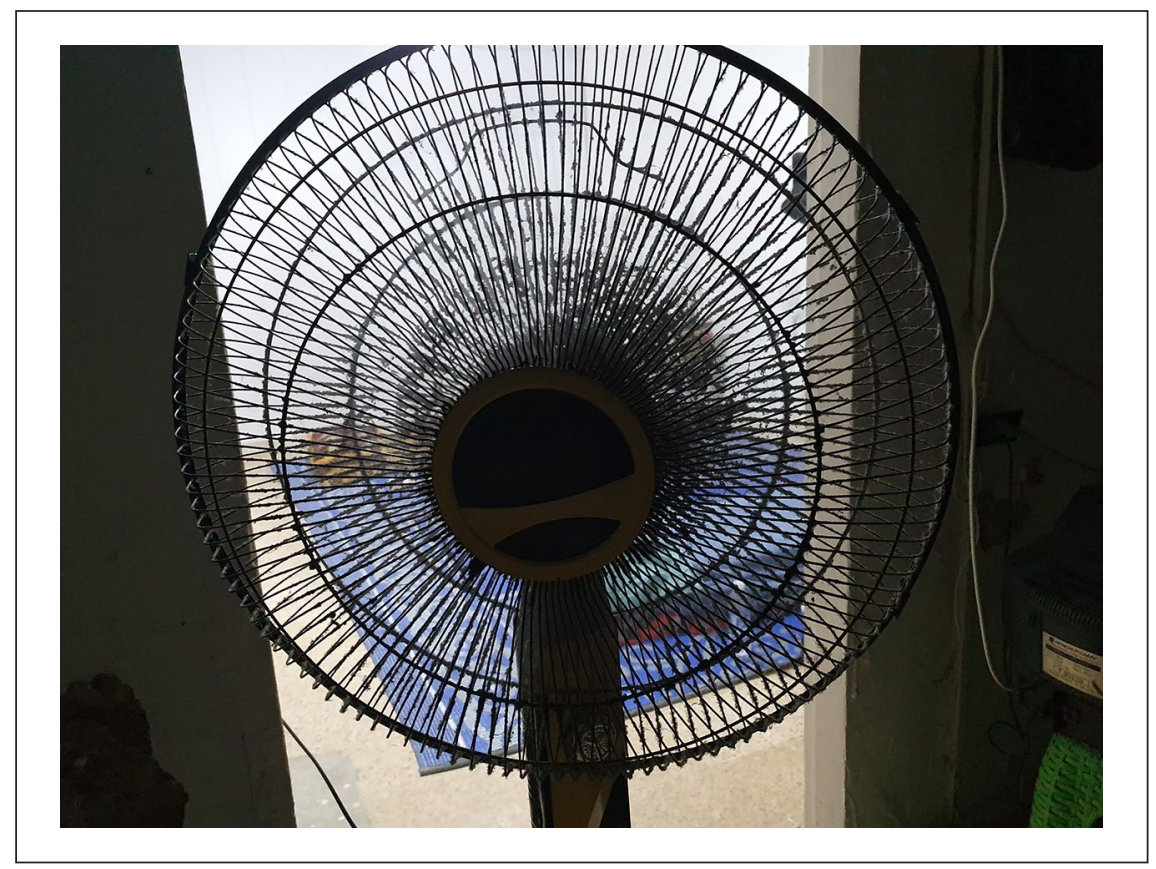

Picture 2. Shatila, 2019. Fan in a dwelling rented by a Syrian man. 
disapproval, as well as acceptance. These sounds shape one of the sensory aspects of the camp: in his work on the city of Naples, Olivier Féraud (2010) stresses that the sound dimension "creates space": "the voice creates social spaces and [. . .] detonations produce spaces of affirmation and otherness" (p. 24). The "vocality"12 of the camp is thus evoked, where the sound environment, other than sounds of a religious nature - the call to prayer five times a day and the reciting of the Koran - is strongly shaped by children's games, discussions in public spaces, calling out, and, often, loud quarrels. The latter fill the narrow alleys and echo relatively far because of the specific acoustics of the place, with the narrow streets and the height of the buildings causing reverberations.

In order to study the perception and production of sounds by the different inhabitants and the boundaries which this relationship to the sound environment defines, I have made several recordings and used different methodological tools.

The first approach was by participant observation. In order to understand how the inhabitants of the camps hear and especially how they evaluate what they hear, in May 2019, I stayed in a ground floor flat in Shatila for 10 days. I stayed with Hasan, a Syrian friend of about 30 years old, the same friend who writes literary texts about the camp. Hasan would permanently leave a fan on in the room and an air extractor above the entrance to a narrow alleyway not more than a meter wide (Picture 2). These appliances, contrary to those put on display by al-Mī' ārī, produce a continual sound in the flat. This kind of sound is sometimes referred to as "white noise," an acoustic buffer which filters out exterior sounds. Hasan likes this atmosphere which enables him to avoid hearing the sounds from the narrow alley, especially the interminable quarrels, which he is documenting for me by recording them on his smartphone (I lent him a Zoom recorder but he preferred to use his phone with which he was more at ease, and which is less noticeable than a recorder because it is more common). The sounds of the fan and of the air extractor can also be considered as "sound walls," the omnipresence of which Schafer observes in the modern world and which are as tangible for modern man as actual walls. These sound walls enclose individuals in their familiar environment and protect them from the outside. Schafer (1994 [1977]: 93) compares them to the castle gardens of the Middle Ages, with their birds and fountains, which contrasted with the hostile exterior environment. In sound 1 , the voices of the inhabitants in the alley are mostly drowned out by the sound of the air extractor. The presence of the neighborhood emerges when the person carrying the microphones (me in this case) walks through the door and enters the alley. The sound decreases and disappears as I enter deeper into the camp.

Sound I. Shatila from Hasan's flat. 8 May 2019, 3.49 pm, binaural microphone, recorded by Nicolas Puig. ${ }^{13}$

Like most Syrians living in the camp, Hasan is careful not to attract attention, nor to enter into conflict with a Palestinian neighbor. The camp is considered safer than other places, such as the adjacent district of Hay el Gharbeh, partly due to the relative solidarity uniting the Palestinians, however divided they may be, and to the security control managed by the Palestinian factions; however, it is dangerous to oppose those who administer this space, even if they are no longer in the majority. 
When I asked him to record sounds which he found significant, Hasan began to collect all the verbal quarrels just as he heard them through the walls of his flat and the filter of the ventilators. For him, the camp's acoustics are strongly marked by the problems that arise between the inhabitants, whether it is Palestinians quarreling with unruly Syrian children, neighborhood quarrels, or recurring scandals provoked by a young person in the narrow alley who drinks and smokes too much. All these are frequent problems, he stressed.

Sound 2. "Problem in the alley" (maŝkal fil-hāra), 12 June 2019, mobile phone, recorded by Hasan.

Asking Nidal, a Palestinian from the camp, to do the same gave a very different result. Here again, the method was not completely successful: Nidal made only a few recordings in 10 days. Nevertheless, his choices reveal the sound environment which he perceives. He thus recorded the voices of children playing in the alley and the musaharātī, the person who awakes those who are fasting so that they eat a meal before sunrise during the month of Ramadan. The musaharātī goes round the streets of the camp (or the town) beating a percussion instrument (usually a darbuka) while calling out ritual expressions in a loud voice, telling those who are fasting to awake. ${ }^{14}$

Sound 3. The musaḥarātī, I6 May 2019, $2.30 \mathrm{am}$, Zoom H2, recorded by Nidal.

Sound 4. Children's games in the narrow alley, 10 May 2019, 3.30 pm, Zoom H2, recorded by Nidal.

For the Palestinians from Shatila, like Nidal, the sound of children's games in the narrow alleys, the call of the musaharātī, but also the gunshots which are often heard inside the camp ${ }^{15}$ (these gunshots are usually to celebrate a wedding or a happy event and are much more rarely provoked by incidents between individuals or factions) contribute to creating the boundaries of a familiar environment which is just as vilified for its mediocre urban characteristics as it is defended for being a last remaining plot of Palestinian land, as well as a space of daily life. The description of the camp's sound environment by Nidal reveals an acoustic community which agrees on a certain number of "sound markers," or soundmarks (Schafer, 1994 [1977]: 10), which characterize the camp by its sounds. For Schafer, the community can be defined in different ways: as a political, geographical, religious, or social entity; but the ideal community can also be usefully defined in acoustic terms. And the house can be appreciated "as an acoustic phenomenon, designed for the first community, the family" (Schafer, 1994 [1977]: 215). Therefore, the domestic space is the first place where the members of the family can intervene, by acting upon their environment by decorating it but also by sonorizing it. This is manifested in the apartments of the camps, first, but not only, by the habits of listening to music, sometimes of reciting the Koran, and of the use of objects belonging to the acoustic space (the space in which they are audible). The will to control the sound environment is visible, in the camp just as in the town in general, by the presence of many caged birds, usually canaries, which are very popular on account of their song (Picture 3). 


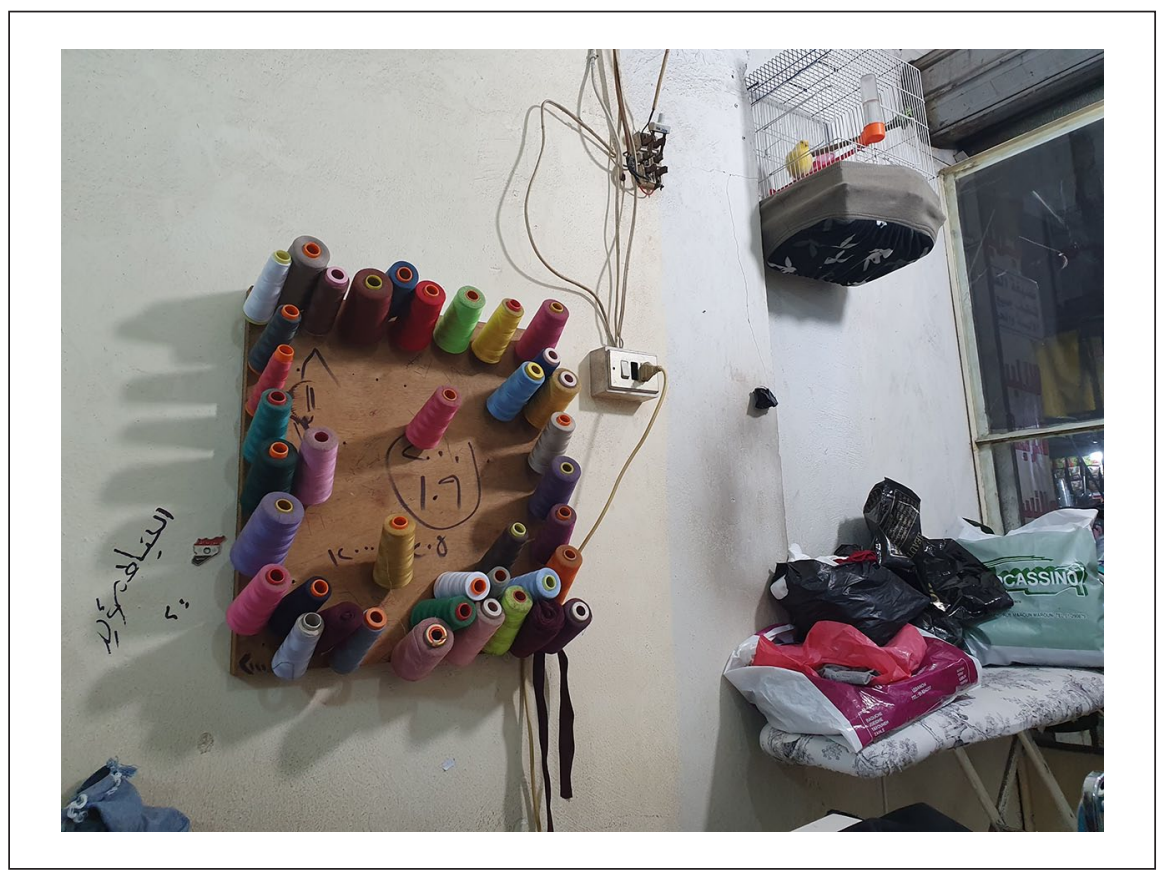

Picture 3. Shatila, 2019. A canary in the store of a Syrian tailor.

Nidal, who has become more aware of the sound environment through our experiences and our discussions, mentioned that during the intervals in Israeli bombing in summer 2006 "we could hear the birds singing": the din of the bombing was replaced by a heavy silence descending upon the town where only birdsong could still be heard. The inclusion of that sound memory illustrates all the importance of the camp as a sensory environment which is both produced and perceived by the inhabitants.

The production of that environment is manifested also by the vocality which has already been alluded to: the Palestinians, or at least some of them, use a particular accent in their vocal expression which derives directly from their legitimacy to occupy that space and to remain there. This vocality is spread throughout the country where it is associated with manifestations of masculinity. In the camp, it plays a role in the new relationship with the Syrians, who have become numerous and, although tolerated, are accused of invading the space. The latter, however, are careful not to get involved in a loud quarrel, or even in an animated discussion. These vocal exchanges, which are as much an expression of competitive behavior between Palestinians as of domination over a foreign resident, can be compared to the vocalization known in Naples as "dare la voce," "giving voice," which "always expresses the act of vocalization, in this instance with an especially loud voice, a verbal statement” (Féraud, 2010: 271).

The sound production of the camp is also the result of several actions such as the use of firecrackers, fireworks, gunshots, or musical processions in the camp to celebrate 
engagements or weddings. All these practices are intentional and send a sound message to the inhabitants of the camp. They depend on objects and instruments, the acoustic sphere of which goes beyond the private and domestic sphere and belongs to the public realm. While this causes no problem in the case of processions which also play the role of banns, firecrackers, and gunshots cause major quarrels: indeed, the authorities try to control the use of firearms in the camp, without really obtaining meaningful results. Those detonations place each resident under their "sound authority" (Féraud, 2010: 418). In addition, the use of firecrackers draws a distinct boundary between Palestinians and Syrians: tolerated when they are used by Palestinian children, they inevitably provoke strong complaints when used by Syrians.

The pre-exilic objects presented at the beginning of this text, the electric fan and the radio, continue to be a part of the daily lives of the inhabitants of the camp. Of course, some offices and authorities have the benefit of air-conditioning, and the use of transistor radios has diminished to be replaced, initially by television and, nowadays, by computer screens and smartphones. Nevertheless, these two sound objects of the material culture are still present in every house of Palestinians as well as Syrians, and of Asian and African migrants (Picture 4). The fact that such banal objects have been chosen to be included among the witnesses of life before 1948 demonstrates the great importance given to those times, since the faintest trace of them has such an evocative power, the power to conjure the presence of historic Palestine.

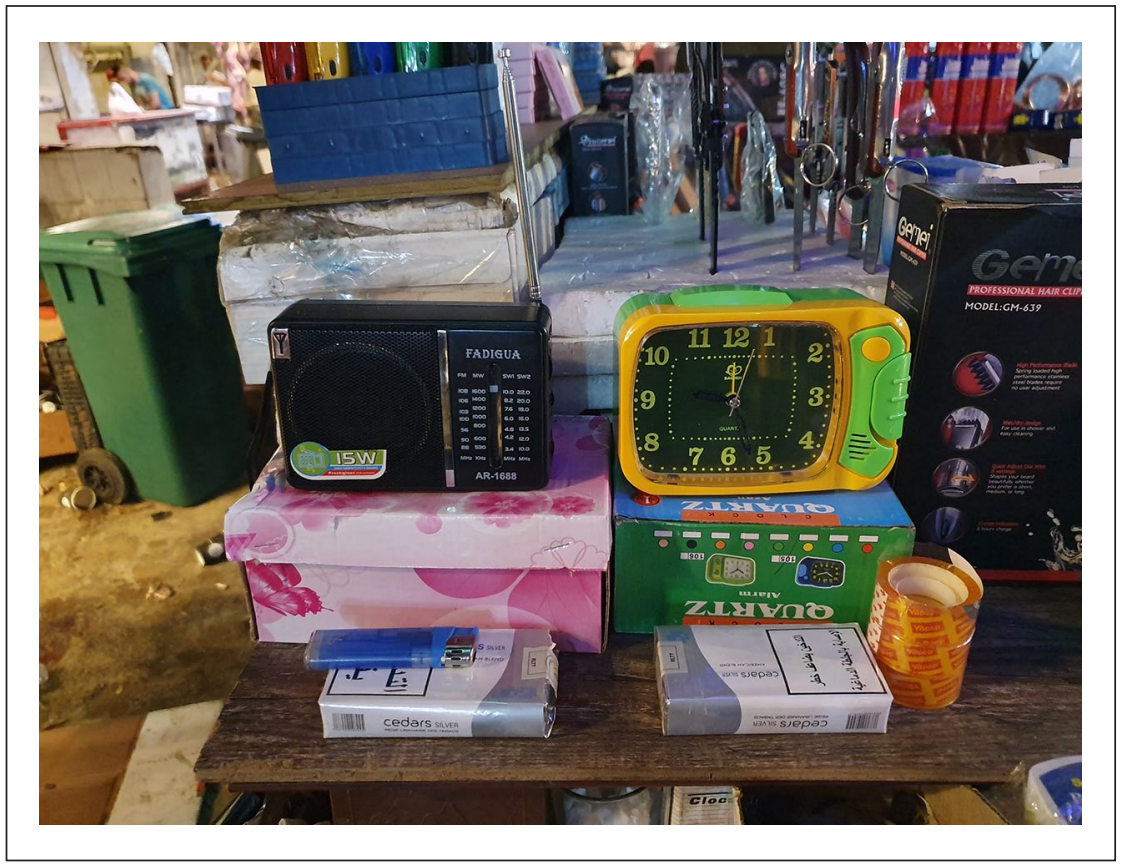

Picture 4. Sabra, 2019. A stand selling small domestic devices. 


\section{Listening to the camp}

To understand the sound perceptions in the camp better, and especially the contrast with the sounds of the nearest surroundings, working with Hala Abou Zaki (a postdoctoral researcher at Oxford Brookes University in England), I used a method which I began using in Cairo with Vincent Battesti in 2011. ${ }^{16}$

We therefore asked to two inhabitants to carry out a sound journey, from Shatila to the neighboring market in Sabra, there and back. The first journey was carried out by a Syrian woman of about 40 years, Um Abdallah, who has been living in Shatila since her marriage in 1994 to a Palestinian from Lebanon, born in 1971 and who is a butcher in Sabra and was present for the commentary. Um Abdallah recounts having been subjected to a degree of ostracism, sometimes bordering on racism, by her in-laws and the inhabitants of the camp, on account of her Syrian nationality. She also had to face accusations aimed at the Syrian government which she is seen to personify by some people. Her husband is originally from Sabra, and he and his family took refuge in Syria in the 1980s, fleeing the Israeli invasion and the ensuing violence. He returned to Lebanon in the early 1990s with his Syrian wife.

The second journey ${ }^{17}$ is by Jamal, a man born in Shatila in 1965 whose family was among the first arrivals in the camp shortly after its exile from Jaffa to Lebanon in 1948. Jamal had to leave the camp for several years when the pro-Syrian factions of Shatila became too threatening because he was a militant of Fatah, the Palestinian liberation movement founded by Yasser Arafat. ${ }^{18} \mathrm{He}$ then returned to his camp and comments on its demographic and urban evolution with a certain resentment.

The two journeys brought to the fore the significant presence of foreigners now in Shatila, and the comments of the participants about this evolution based on their sound experience, which is reflected here by the hearing of different languages (Sinhala, Bengali, Amharic) and Arabic accents (Lebanese, Syrian, Palestinian). In that sense, the journeys bring to the fore the horizontal dimension of Babel which now characterizes the market of Sabra next to Shatila, and the complex nature of the camp's population. They emphasize the vocality of the places, and during the reactivated listening the participants take part in a discursive construction of the other.

The Syrians, whose different local Arabic accents are recognizable, are very present in the recordings. Jamal is irritated by this strong presence, while Um Abdallah, herself Syrian, is much more tolerant. Indeed, Jamal is experiencing a feeling of loss of status and of bearings with regard to the transformation of space in Shatila. He denounces the camp's degradation and the fact that it is gradually being taken over from the Palestinians. However, to him and his generation, Shatila represents a strong point of reference of identity and politics, and constituted, with the neighboring gathering of Sabra, a central point of Palestinian politics and culture which he and his comrades of Fatah defended with arms during the War of the Camps. ${ }^{19}$

The considerable presence of foreigners, of Syrians, and of numerous male and female Asian workers, crowding the market and renting flats in the camp and its surrounding area upsets the Palestinian inhabitants. ${ }^{20}$ Jamal stated that he has no daily contact with the migrants from Bangladesh, even if he knows them. He thus differentiates the Syrian, Lebanese, and Palestinian sellers from the Bangladeshis "who come on specific days, on 
Sundays, who have their own shops and merchandise which they sell here" (commentary from the journey of Jamal 07:28). The latter are then referred to as "foreign sellers" (commentary from the journey of Jamal 14:14). The voices of the Arabs in the market (Syrian, Lebanese, and Palestinian voices) are therefore distinguished in the journey, including Palestinians speaking in a Lebanese accent (commentary from the journey of Jamal 12:18). However, in that case, knowing the person who is speaking plays an important role in identification.

In contrast, Jamal was not so precise in describing the voices of Asian migrants since he qualified a group of Bangladeshis in conversation as Sri Lankan (commentary from the journey of Jamal 18:35). At the time of the investigation, in November 2012, Jamal said that he got confused between the Asians in the market: to him they are all the same and he does not differentiate between a Bangladeshi, an Indian, and a Sri Lankan, even if he knows that some of the Bangladeshis have just come to live in the camp. ${ }^{21}$ He seems to glide over this environment of the migrants and the market, having little grasp of it. Finally, the first people he met when he goes out of his house during his journey were rowdy Syrian children; he admitted that he would have willingly told them off. For Jamal, "to belong to the camp" (min al-mukhayam) means to be Palestinian, so he does not consider the non-Palestinian residents to be part of it.

Sound 5. The start of the journey, 30 October 2012, binaural microphone, recorded by Jamal.

Abu Abdallah, the husband of Um Abdallah who carried out the first sound journey, has developed a fairly circumstantial vision of the nationalities present (he intervenes during his wife's commentary on her recording).

He distinguishes the "Arab" foreigners - Syrians, Iraqis, Palestinians-from Asian migrants-Filipinos, Sri Lankans, and Bangladeshis-who occupy the market from Saturday night to Sunday morning (commentary from the journey of Jamal 38:41).

Like Jamal and like what frequently happens in the market, Abu Abdallah often uses the demonym, the name of the country, to refer to its nationals, the Philippines, Sri Lanka, or Bangladesh: "You can find the whole world in Lebanon now: Sri Lanka, Bangladesh, Egyptians, Filipinos. Nearly all of Asia is here [. . .]." He then groups them according to their cultural and religious customs: "they all eat chili pepper, and listen to the same music." The only difference between these national groups is their religion, "Muslims, Christians, and Sikhs."

His wife, Um Abdallah, began her journey with a purchase in Shatila. While she was still on the camp border, her microphones captured the discussion between a Lebanese woman and two Sri Lankan women. After the former assured the migrants that there was no tsunami in Lebanon, they continued to discuss the subject. Um Abdallah reported the discussion:

They are speaking about a tsunami. She [the migrant woman] asked her [the Lebanese woman]: "And what if there was a tsunami in Lebanon?" So she [the Lebanese woman] replied: "We all die, that's normal" [laughter]. 
Then, the Sri Lankan woman spoke with her friend in Sinhalese (commentary from the journey of Um Abdallah 13:33). She also heard local voices which she distinguished easily: "Most are Palestinian and Lebanese, a few Syrian" (commentary from the journey of Um Abdallah 15:26).

Sound 6. 30 October 2012, binaural microphone, recorded by Um Abdallah.

The conversation detailed earlier begins at 0:45. Note the sounds of footsteps, the song of caged birds, and the small loudspeaker in front of a shop.

Unlike her husband and Jamal, Um Abdallah did not use stereotypes to talk about the foreigners in Sabra, she simply described their interactions. She did not sum up the Asian women using general categories. She then entered the Sabra vegetable market to buy something. In her commentary, she described the crowd which she perceived through sound. Within this stream of sound, the voices of Syrian vendors, who are numerous in this part of the market, can be heard (29:33-30:30).

The recordings and commentaries thus emphasize the specific character of the different areas of Sabra and Shatila and of their respective inhabitants. The voices of the Syrian merchants, who are in the majority in the vegetable market, are omnipresent, while the background noise characterizes the whole area: the sound of the Vespa engines and religious sound markers (reciting of the Koran, the call to prayer from the mosque). Then, on her journey, Um Abdallah came across some Syrians who occupied the sound space because there are so many of them in the market. Her Palestinian husband claimed that he could recognize where in Syria they came from (Aleppo, Latakia . . .).

Finally, the sound environment in the camp is sufficiently specific for Um Abdallah to know her location due to the voices of children playing outside at nightfall, which indicates entry in a space which is already partially private, and is an extension of domestic space (01:05:06).

This impression of threshold is also noticed by Jamal, who identified when he was moving from the camp to the avenue of Sabra due to the change in sound atmosphere: "Here, I have arrived at the beginning of the camp which leads onto Sabra Avenue because there is a lot of noise of two-wheeled vehicles and cars" (03:13). These impressions of threshold pointed out by the informants indicate the role that hearing plays in establishing a familiarity with the environment. They trace the sensory boundaries between the normal camp space and the more open and mobile space of Sabra where most encounters with foreigners from near and far occur.

\section{Conclusion: Sensory politics}

Sensory production and perception indicate the existence of sensory politics; political orders provoking humanitarian crisis of variable duration that affect the very concrete living environments. The refugees' criticism of their situation is based on two kinds of criteria. The first is geopolitical and historical, relegating in the long term the Palestinians to the limits of citizenship. The second is closely connected to experience and the daily living conditions as much from the socioeconomic as from the sensory point of view. The 
sound environment of the camp thus depends on the informal urban production by the inhabitants who deal with the town-planning norms of the UNRWA and the Lebanese government (the limited surface area of the camp, the limits on construction, the characteristics of building materials, the lack of infrastructure and town amenities) in a context of influx of refugees from Syria, of Asian migrants, and of poor Lebanese.

From that point of view, the sounds of children escaping overcrowded apartments, the presence of the noise of engines and generators, but also the musical processions, the fireworks, and the sounds of gunfire are the consequences as much of the characteristics of the urban environment as of a more or less conflictual social situation. In the same way, in the visual domain, "the canopy of tangled electrical wires hanging over every alley of Shatila maps complex political and socioeconomic struggles taking place both within the camp and between residents and the surrounding city" (Allan, 2013: 101). In these ordeals, which in the case of Palestinian refugees have lasted several generations, "the participants experience social vulnerability, due precisely to their feelings of uncertainty concerning the reality" (Lemieux, 2012: 174). The planning practices related to the sensory elements (lighting, water, space, soundscapes, etc.) of that environment, however microscopic they might be, represent the refugees' many attempts to control their environment in a context of limited possibilities, of the poor quality of building materials, of energy rationing, of difficult access to water. Among them, the sound practices give the refugee camp, which over time has become a poor cosmopolitan district, a specific identity, and contribute to establishing a familiarity with the spaces, while at the same time creating boundaries between groups. They satisfy the need of all the residents to act upon and in their living space, from the urban margins where they are "confined" in the long term by forces which are beyond them and by the actions of sensory politics.

\section{Declaration of Conflicting Interests}

The author declared no potential conflicts of interest with respect to the research, authorship, and/ or publication of this article.

\section{Funding}

The author received no financial support for the research, authorship, and/or publication of this article.

\section{ORCID iD}

Nicolas Puig (iD https://orcid.org/0000-0003-4828-9395

\section{Notes}

1. This topic has been of interest to researchers for many years, such that it would take too long to list all the social science research done on Palestinian refugees in Lebanon. I cite here only a few primary examples which tackle this question from different perspectives: oral history and Palestinian history in Lebanon: Abou Zaki (2017), Sayigh (1994), Sfeir (2008); urban insertions: Doraï and Puig (2012); the political sociology of the camps: Latif (2008), Peteet (2005), Puig (2014); the socio-political identity and dynamics of the camps: Hanafi (2010), Khalidi (2010); the diaspora and the dimension of exile: Doraï (2006). 
2. Translator's note: Our translation. Unless otherwise stated, all translations of cited foreign language material in this article are our own.

3. Jean-François Augoyard does not provide a definition of "audible modes" in his work. They can be conceived of as ways of accessing reality through hearing.

4. A gathering is a district which is integrated into the Lebanese municipality where the majority of the inhabitants are Palestinian. In this case, it is Lebanon which manages the town planning and roads, unlike in the camps where these services are provided by the UNRWA (see note 6 below).

5. Population and Housing Census in Palestinian Camps and Gatherings in Lebanon, 2017 [online: http://www.cas.gov.lb/images/PressRoom/census\%20findings_2017_en.pdf] and personal communication with Hala Abou Zaki.

6. The United Nations Relief and Works Agency (UNRWA) for Palestine Refugees in the Near East was established in 1949. See: http://www.unrwa.org/ (accessed 9 April 2020).

7. The dabkeh, the usual Latin transcription of $d a b k \bar{a}$, is a festive dance of the Near East. The word is also used for a regional musical style which is considered "popular," or sha' $a b \bar{i}$.

8. https://www.youtube.com/watch? $\mathrm{v}=$ ZcC5QGK3-Lc (accessed 9 April 2020).

9. They are now strengthened by the very professional work of an association of young Palestinian journalists (from Lebanon and Syria) who have created a Facebook channel (Kāmbji in Arabic, translated by them as Campji, "campist") fed with short videos about questions concerning life in the camps (such as rumors, for example).

10. When this article was submitted, Hasan had left Lebanon for Egypt, where he has been living since the beginning of 2020 .

11. The same term of camp (mukhayam) is used to describe spaces for Syrian refugees in the Bekaa plain, especially. These refugees rent plots there on which to set up a makeshift dwelling in a well-defined and organized camp, which is under the responsibility of a caretaker agent. Relatively recent, these forms of habitation and the sound atmosphere are very different from those in the old urban camps which have acquired a patina due to the length of time their inhabitants have lived there.

12. Vocality can be defined as an "act of voice" (Féraud, 2010: 24).

13. All sounds referred to in this article can be accessed and listened to here: https://zenodo.org/ record/4012489\#.X1H0UNX-_6Y

14. At my request, Nidal carefully ended his recording by listing the data which enabled it to be identified later (date, time, place).

15. When there are gunshots, if I am inside the camp Nidal never fails to check that I am safe. These shots, although relatively banal, nevertheless always provoke people to listen alertly.

16. The method consists of equipping the participants with binaural microphones to use on their journeys on foot in a given space (a district, for example). When they return, the participants listen to their recording (it is therefore a reactivated listening) and are invited to describe and comment on the recorded sounds (cf. Battesti and Puig, 2016, 2020). The experiment in Lebanon was conducted at the end of 2012.

17. To access the complete transcription of the commentaries of both participants, see http:// vbat.org/spip.php?article749 (accessed 10 April 2020). The time codes in the text refer to the Arabic transcriptions (transcriptions done by Manal Jaafar).

18. The War of the Camps (1985-1987) involved fighting between the Amal militia, supported by Syria, and the Palestine Liberation Organization (PLO) in Lebanon. All of the Sabra camp and $85 \%$ of the Shatila camp were destroyed.

19. Abou Zaki (2017) points out that this episode: 
"is an important time marker in their lives and the life of the camp. At that period, Shatila was almost entirely destroyed and its inhabitants were dispersed. Control of the camp was put in the hands of the pro-Syrian Palestinian factions. That war has profoundly transformed the social and political structure of the camp, as well as creating a real split between the Palestinians and the Lebanese Shiites who were living side by side." (p. 60)

20. If we are to believe the 2017 census, more than half of the inhabitants of Shatila are Syrian.

21. This may have changed since then because the Bangladeshis have settled in Shatila and Sabra for the long term: the discursive construction of the other is evolving, to varying degrees.

\section{References}

Abou Zaki H (2017) Chatila à la croisée des chemins : guerres, mémoires et urbanités d'un camp de réfugiés palestiniens au Liban. $\mathrm{PhD}$ Thesis, EHESS, Paris.

Allan D (2013) Refugees of the Revolution: Experiences of Palestinian Exile. Stanford, CA: Stanford University Press.

Augoyard JF (2003) Une sociabilité à entendre. Espaces et sociétés, “Ambiances et espaces sonores" Special Issue 115(4): 25-42.

Battesti V and Puig N (2016) "The sound of society": A method for investigating sound perception in Cairo. The Senses and Society 11(3): 298-319.

Battesti V and Puig N (2020) Towards a sonic ecology of urban life: Ethnography of sound perception in Cairo. The Senses and Society 15(2): 170-191.

Doraï MK (2006) Les Réfugiés palestiniens du Liban : une géographie de l'exil. Paris: CNRS Éditions, "Moyen-Orient" series.

Doraï MK and Puig N (eds) (2012) L'Urbanité des marges : migrants et réfugiés dans les villes du Proche-Orient. Beirut: IFPO; Paris: Éditions Téraèdre, "Un lointain si proche" series.

Féraud O (2010) Voix publiques. Environnements sonores, représentations et usages d'habitation dans un quartier populaire de Naples. PhD Thesis, EHESS, Paris.

Hanafi S (2010) Governing Palestinian refugee camps in the Arab East: Governmentalities in search of legitimacy. Working paper series \#1. Beirut: American University of Beirut, Issam Fares Institute.

Khalidi MA (ed.) (2010) Manifestations of Identity: The Lived Reality of Palestinian Refugees in Lebanon. Beirut: Institute for Palestine Studies.

Latif N (2008) Space, power and identity in a Palestinian refugee camp. Asylon(s) 5. Available at: http://www.reseau-terra.eu/article800.html (accessed 6 July 2020).

Lemieux C (2012) Peut-on ne pas être constructiviste ? Politix 100(4): 169-187.

Peteet J (2005) Landscape of Hope and Despair: Palestinian Refugee Camps. Philadelphia, PA: University of Pennsylvania Press.

Puig N (2009) Exils décalés. Les registres de la nostalgie dans les musiques palestiniennes au Liban. Revue européenne des migrations internationales 25(2): 83-100.

Puig N (2010) Welcome to the camps. The emergence of Palestinian rap in Lebanon, a new social and political song. In: Khalidi MA (ed.) Manifestations of Identity: The Lived Reality of Palestinian Refugees in Lebanon. Beirut: Institute for Palestine Studies and IFPO, pp. 109-124.

Puig N (2014) Nahr al-Bared (Liban). Le camp et ses doubles. In: Agier M (ed.) Un monde de camps. Paris: La Découverte, pp. 178-192.

Sayigh R (1994) Too Many Enemies: The Palestinian Experience in Lebanon. London: ZED Books.

Schafer RM (1994 [1977]) The Soundscape: Our Sonic Environment and the Tuning of the World. Rochester, NY: Destiny Books. 
Sfeir J (2008) L'exil palestinien au Liban. Le temps des origines (1947-1952). Paris: Karthala; Beirut: IFPO.

Sterne J (2003) The Audible past: Cultural Origins of Sound Reproduction. Durham, NC: London: Duke University Press.

\section{Author biography}

Nicolas Puig is a researcher in social anthropology at the Migration and Societies Research Unit (IRD, CNRS, University of Paris and University of Nice). He is currently working in Egypt and Lebanon on the ordinary fabric of urban environments and on the relations between music, sound practices, and urbanities. He is particularly interested in the insertions, which depend on contrasting temporalities, of migrants and refugees of various origins in Lebanese cities, Beirut in the first place.

Publications: https://cv.archives-ouvertes.fr/nicolas-puig 